\title{
SUSTAINABLE RETIREMENT VILLAGE FOR OLDER PEOPLE: A CASE STUDY IN BRISBANE, AUSTRALIA
}

\author{
Bo XIA a, Jian ZUO b, Martin SKITMORE a, Qing CHEN ${ }^{\text {c,* }}{ }^{\text {, Ayomi RARASATI a }}$ \\ a School of Civil Engineering and Built Environment, Queensland University of Technology, Garden \\ Point Campus, 2 George Street, Brisbane QLD 4001, Australia \\ ${ }^{b}$ School of Natural and Built Environments, University of South Australia, City East Campus, North \\ Tce, Adelaide, SA 5001 Australia \\ ${ }^{c}$ Department of Building and Real Estate, The Hong Kong Polytechnic University, Hung Hum, Kow- \\ loon, Hong Kong, China
}

Received 18 September 2013; accepted 3 February 2014

\begin{abstract}
Retirement villages are regarded as a viable accommodation option for the ever increasing ageing population in Australia. This paper aims to identify sustainability features and practices adopted in retirement villages and associated benefits to improve the life quality of older people. A case study of an existing retirement village $10 \mathrm{kms}$ from Brisbane CBD was conducted involving a series of interviews with the village managers and residents together with documents relating to the village's operations and activities. The environmentally friendly features that were incorporated into the development mainly include green design for the site and floor plan and waste management in daily operation. More importantly, a variety of facilities are provided to strengthen the social engagement and interactions among the residents. Additionally, different daily services are provided to assist independent living and improve the health conditions of residents. Also, the relatively low vacancy rate in this village indicates that these sustainability features offer good value of money for the residents. The paper provides a first look at sustainable retirement villages in terms of triple bottom line sustainability with emphasis on social aspects, reveals the importance in maintaining an appropriate balance, and provides examples of how this can be achieved in practice.
\end{abstract}

KEYWORDS: Retirement village; Sustainability; Triple bottom line; Case study; Australia

\section{INTRODUCTION}

In Australia, the proportion of the population aged 65 years and over increased from $11.1 \%$ to $13.5 \%$ between 1990 and 2010 and is expected to continue to increase steadily to around $20 \%$ by 2056 (Australia Bureau of Statistics 2010). This demographic change has social and economic consequences for such matters as the availability of resources, community services, pensions, health care, the work force and the provision of alternative housing for older people (United Nations 2002).

Housing is an important determinant of the good health of people in later life, as they not only need a secure and comfortable home but also because housing provides a social surrounding for

\footnotetext{
* Corresponding author. E-mail: richard.q.ch@gmail.com
}

older people to interact with others in the community (Lawton, Cohen 1974; Cotter et al. 2012). The reduced physical performance of older people means that good access to amenities, ease of maintenance of living places and operations of facilities, need for companionship, security and provision of medical services are among their unique ergonomic requirements (Pinto et al. 1997; Dul et al. 2012). Additionally, older people in general tend to have a reduced financial capability after retirement (Poterba et al. 2011), making the affordability and maintenance costs of their accommodation always a concern in choosing between housing options. Furthermore, in contrast with traditional negative stereotypical expectations, older people today have a long healthy life expectancy and substantial social engagement (Cornwell, Waite 2009). However, these issues are frequently overlooked in the drive to provide affordable housing for younger people, 
and new construction is often unable to meet the more specialized housing needs of people as they increase in age (Nummelin 2005).

The retirement village is one of the viable housing options that can accommodate and care for the growing aging population. A number of Australian studies have found that retirement villages have a positive impact on the independence, perceived health and social relationships, reliance on community services and social integration of the residents (e.g. Buys 2000, 2001; Gardner et al. 2005; Bernard et al. 2007; Buys, Miller 2007). Current literature also indicates that retirement villages have a great potential to achieve a person-environment balance, a component of Environmental Gerontology Theory, which emphasizes the importance of the interrelationship between ageing persons and their socio-physical environment, and that the quality of their living environment should match their personal competence (Lawton 1982; Wahl, Gitlin 2007).

However, despite the clear importance and great potential of retirement villages to accommodate older people, the current retirement village industry fails to attract most of Australian older people, with only $4 \%$ of Australians aged 65 and over currently living in retirement villages, compared with more than $8 \%$ in the USA equivalent (Omoto, Aldrich 2006). Of particular note is that, for a variety of reasons (such as failing health, lack of security, difficulty in managing large property, social isolation, poor public transport, loneliness, desire for an alternative lifestyle, etc), many older people face the prospect of major life-style changes in terms of loss of independence and privacy for example (Crisp et al. 2013). As Gilleard and Higgs (2005) observe, an increasing number of older people contemplate whether or not to "replace the community of their past with new identities which affirm a new stage in life". Retirement villages need to be responsive to this situation in providing dynamic environments for independent living and a good quality of life. Many are not however, failing to fully address even such basic needs of older people as size, energy efficiency and requirements for ongoing maintenance, provision for social activities and belongingness (Nummelin 2005). Prior study also shows affordability to be a constant major concern of potential retirees, with many retirement villages being rather myopic business ventures created for the sole purpose of generating high financial returns to the owners (Barker et al. 2012).
To adequately house and care for the growing aging population, there is an urgent need for retirement villages to provide a living environment that fully addresses the ergonomic requirements of older people, their reduced financial situation, and social needs for an active aging life style. A case study of a retirement village in Brisbane, Australia, has been conducted to identify the sustainable practices relating mainly to the facilities management and services provided. This contains implications of both the operation of retirement villages on current practices and the industry's future.

\section{BACKGROUND}

The term 'retirement village' in the Australian context normally refers to a community of independently living people, predominantly aged 55 years and over with associated facilities (NSW Fair Trading 2011). In some villages, serviced apartments and low/high care accommodation are also provided and operated according to government regulations. According to the Retirement Village Association (RVA 2011), there are approximately 138,000 people living in 1,850 retirement villages around the country, with growth in the retirement living sector expected to increase almost threefold over the next four decades.

Sustainability, in the form of eco-friendliness, is gaining momentum in the construction industry in Australia and worldwide (Xia et al. 2013). Sibley et al.'s (2003) triple bottom line concept offers a significant step forward by including both economic and social aspects as sustainability components in their own right. This is particularly germane of residential development (e.g. green buildings and sustainable urban planning) for older persons, where the implication of the combination of aging and sustainability on health and well-being has received little scientific attention thus far (Pillemer et al. 2011).

For housing in general, the triple bottom line concept involves the consideration of the three dimensions of environmental sustainability, economic sustainability and social sustainability. The elements of environmental sustainability include well-known issues relating to resource efficiency, decreased impact on climate change and the ecological system. Economic sustainability means savings in construction costs, running costs, living costs, costs of future modifications and longterm maintenance, good resale value and cost efficiency to the community. Social sustainability, 
on the other hand, can be identified as including design for flexibility, comfort, safety, security, belongingness and social engagement. These three sustainability dimensions are also interrelated. For example, investments in green building may result in energy cost savings, higher level of occupant satisfaction and lower impacts on human health (Zuo, Zhao 2014). The triple bottom line approach provides a holistic way of viewing sustainable development (Sridhar 2011).

A sustainable retirement village (SRV) therefore needs to respond to the environmental, economical and social sustainability requirements of senior citizens. In environmental terms, public health research, for example, indicates that environmental threats disproportionately compromise the health of the older population. In particular, a good indoor environmental quality is necessary to support the health of older people due to their heightened vulnerability to environmental threats such as exposure to neurotoxins and air pollution (Stein et al. 2008; Lee et al. 2012; Wargocki, Wyon 2012). A SRV should, therefore, have a physical environment with a suitable level of indoor environmental quality, energy efficiency, security, ease of access and maintenance.

On the other hand, a SRV needs to be affordable to its residents. Some current studies (Barker et al. 2012; Zuo et al. 2014) suggest that, although almost all older people desire a living environment that is more eco-friendly, affordability is always a major concern. This is understandable considering that older people experience reduced financial capabilities after their retirement and live mainly on pensions. The implications of this concern both the initial cost of moving into a retirement village and recurrent maintenance and service costs involved.

Regarding social sustainability, a SRV needs to facilitate an active and healthy life style for residents. The majority of residents believe that social activities, friendships and social networks are importance for their quality of life (Buys 2000; Barker et al. 2012). A wide range of research demonstrates the importance of social support in later life (Golden et al. 2009; Grundy, Read 2012). A well-planned SRV can create opportunities to develop friendship networks and participate in a range of activities in the village and in the wider community.

With the widespread acceptance of sustainability ideas and increasing numbers of older people moving into retirement villages, a SRV will provide a timely intervention to help address their unique requirements and improved quality of life (Zuo et al. 2012).

\section{RESEARCH METHODOLOGY}

Despite the increasing demand for SRVs, few studies have investigated their provision. Due to the lack of adequate historical data for quantitative analysis, a case study of a retirement village was conducted to identify the sustainable practices involved. Considering the retirement village was developed 21 years ago, the case study mainly focused on its operation, facilities management and community services within the community. Special emphasis was placed on the following questions:

1. What are the environmental friendly features for reducing the use of natural resources?

2. What are facilities and services available for improving the quality of social life of residents?

3. What are the cost implications of introducing sustainability features into the retirement village?

The selected project, the Keperra Sanctuary, was developed by Lend Lease, one of Australasia's leading owner, operator and developers of senior living communities. Lend Lease employs 3000 people in the retirement sector and manages a portfolio of 70 retirement villages across both Australia and New Zealand. The company has extensive experience of an integrated range of services, including asset and property management, design, development management, investment management and sustainability for retirement communities.

A series of interviews were conducted with the village's senior managers and residents. For the senior managers, these comprised one-hour long semi-structured interviews with the village manager and three facility and maintenance managers, with an average of more than 10 years of experience in retirement village development and management, and an extensive, in-depth, knowledge of residential retirement developments and operations. The main points of discussion centred on the care facilities and services available in the retirement village, the sustainability practices used in its operation, the motivation for sustainability practices and the concerns of the facility managers. The interviews with residents involved a convenience sample arising as a result of a tour of the whole retirement village conducted with the assistance of the village manager, in which all the facilities and services and different types of 
units were presented in detail. This enabled the research team to later approach a number of residents in their units and solicit candid views and experiences concerning their living environment. Additionally, documents comprising resident information books and communication papers such as the village news and facilities manager's reports were inspected. Taken together, therefore, the collected data represents a comprehensive picture of the village development.

\section{CASE STUDY}

\section{Background and context}

As a private independent-living retirement village, the Keperra Sanctuary is located at 998 Samford Road, Keperra, approximately 10 kilometres northwest of Brisbane CBD (see Fig. 1).

Brisbane is in the southeast corner Queensland, having a humid subtropical climate with warm to hot and humid summers and dry moderately warm winters. The village is close to amenities such as transport, health services, stores and libraries. There is a bus stop a few hundred metres from the village entrance and Keperra train station is just one and a half kilometres away. The retirement village is on the site of an old quarry, some of which still remains. There are 254 homes comprising one to three bedrooms units. In addition to the retirement village, Keperra Sanctuary also has a separately managed Aged Care facility, which provides low level care accommodation for up to 49 residents in both single and double rooms.

Keperra Sanctuary was first developed by IOOF (a friendly society called the Independent Order of Odd Fellows), and then owned and managed by Retirement By Design until Lend Lease Core Plus

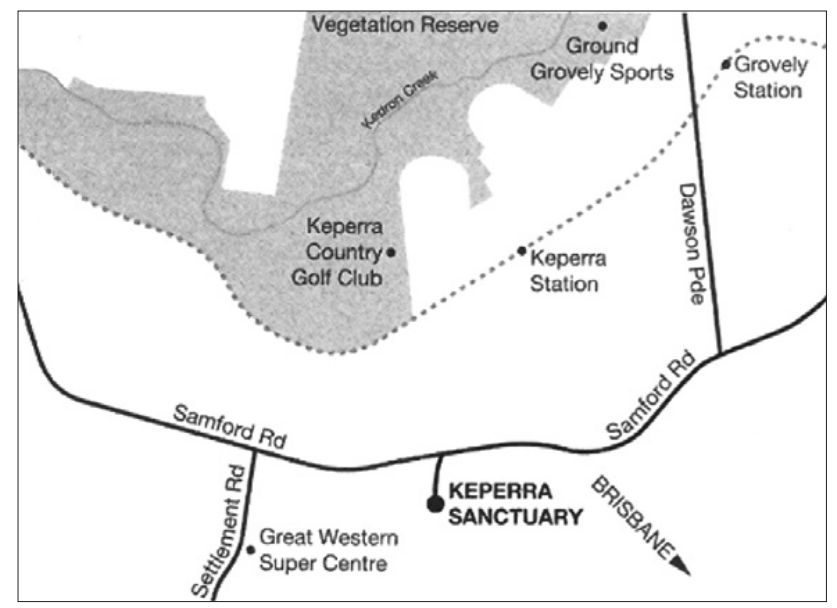

Fig. 1. Location of Keperra Sanctuary, Courtesy of Keperra Sanctuary, Lend Lease
Fund bought the village in 2004. Lend Lease took over the management rights in 2012 and bought the village from Lend Lease Core Plus Fund in March 2013. Lend Lease aspires to be a sustainable leader in the property and infrastructure sectors, and claims to be committed to lead the global transition to a low-carbon, energy-efficient, and resource-conservation model that both reflects and advances social and environmental best practice. Although Keperra Sanctuary was built two decades ago, the planning and design also incorporates green features for energy saving, such as climate considerate landscaping, and the use of insulated brick external walls to keep the buildings cooler in summer and warmer in winter in the prevailing humid subtropical climate. With the integrated experience of facilities and operation management, a collection of green practices has been adopted in the village in order to provide a sustainable community for the active ageing of its residents.

\section{Landscaping and design}

The planning and design of Keperra Sanctuary is based on the concept of environmental and social friendliness. Figure 2 shows the site plan of the village. The whole village is located to the north side of the Bellevue Hill, which helps to reduce the amount of cold wind in winter. Additionally, the retirement village is surrounded by nearly 100 acres of natural bushland, so that residents can enjoy the beauty of the natural scenery away from busy city life. There is a residential community to the north, and a large shopping centre and public transport immediately to the west of the site. This is regarded as ideal for a retirement village as it is important for residents to be connected with the local community (Zuo et al. 2012). Remaining socially active is considered very important for a high quality life for older people after their retirement. Additionally, the location is convenient for family visits - another important factor affecting the decision to move into a retirement village (Buys 2000).

The community centre is located in the middle of the village and is easily accessible by link road to all the units. In the community centre, the village manager and staff manage the dayto-day running of the village and help organise events and activities. As well as involving daily administration tasks, the village manager has the responsibility to ensure that the facilities and services offered in the village meet the residents' expectations. This involves managing the staff and contractors (e.g. gardeners and cleaners) to make sure the grounds, gardens, facilities and buildings 


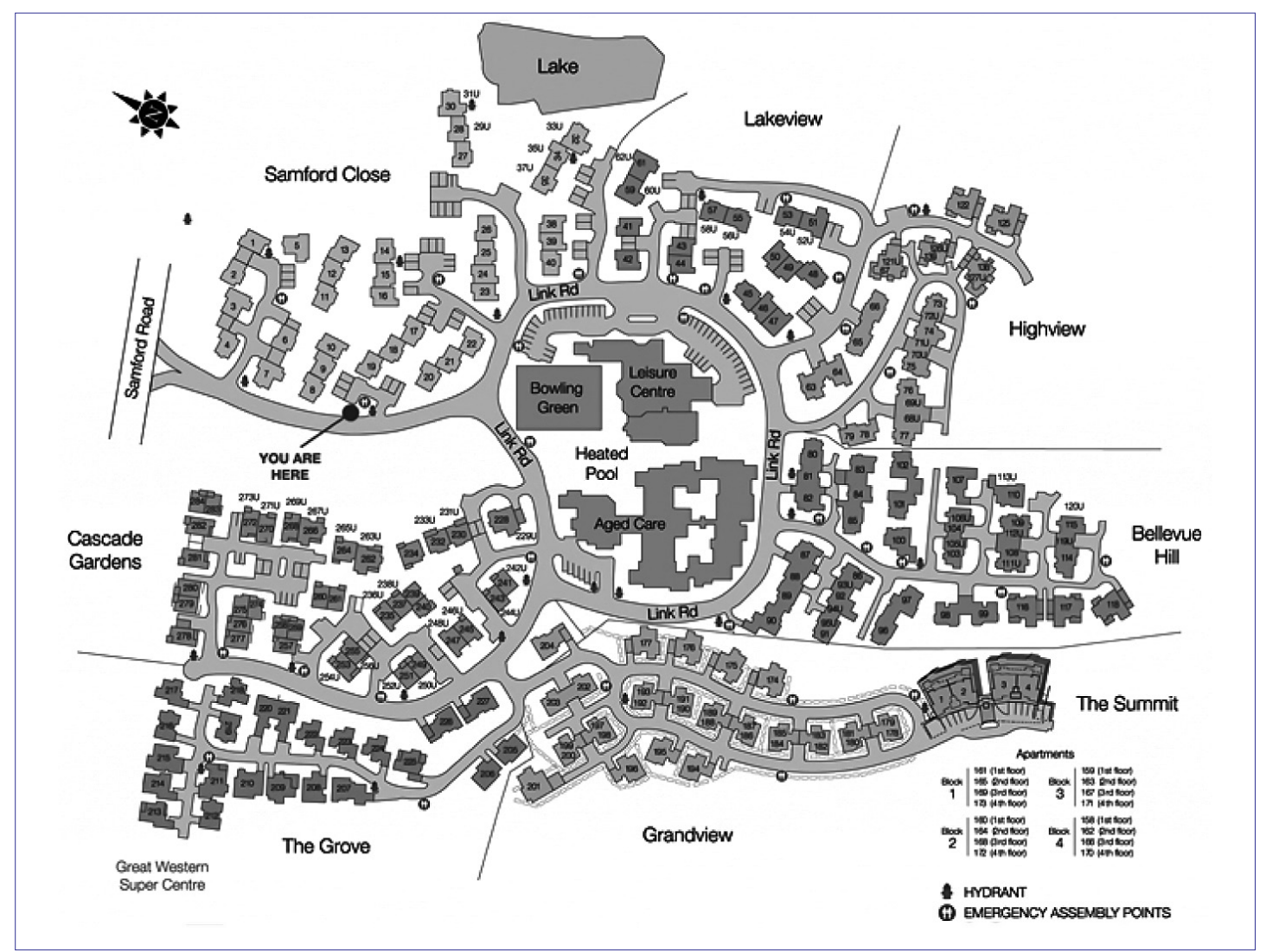

Fig. 2. Site plan of Keperra Sanctuary, Courtesy of Keperra Sanctuary, Lend Lease

are well maintained. Residents unable to live independently and in need of higher-level aged care service, can also apply to move into the Aged Care centre adjacent to the community centre.

The majority of units do not have entrance stairs, which is very convenient for residents with mobility difficulties. Notably, according to the village manger, the two lakeside units that do have stairs do not sell well.

Most of the units face north to take full advantage of natural sunlight. The benefit of this in the Southern Hemisphere is that this maximises exposure to winter sun, therefore helping to heat the units during the colder winter weather. Most of the units also have south facing windows for natural ventilation in order to provide a cool breeze in summer. By optimising the orientation of the windows and doors throughout the units, anticipated reductions in heating and cooling costs are achieved. Additionally, the inside space of the units is relatively open, with wide doorways and large open bathrooms, allowing easy access for residents to all areas.

Within the village, there are 31 emergency assembly points, all clearly identified with Emergency Assembly Point signs, which provide safe locations in times of emergency evacuation. There are outdoor benches along the village link road for residents to take rest, providing a walking friendly environment. Other green features in the village include the use of water tanks to conserve water in the community centre and houses. The use of solar heating for the pool also reduces electricity consumption. The village also pumps water from the lake to a mobile tank for use in water pressuring footpaths and walkways.

Waste management is another major focus. Three types of bins are provided - general waste bins, recycle waste bins, and paper and cardboard bins - and which encourage residents to recycle as much as possible. Used papers are a major waste in the village, and a paper and cardboard recycling facility is provided to minimise this and reduce the cost of general waste disposal. Bin collection costs approximately AUD $\$ 10$ per bin, and there are 30 bin loads of recycle paper and cardboard per month. By using the cardboard and paper recycling facility, the village saves approximately AUD $\$ 300$ per month in collections.

\section{Facilities and services}

To make an enjoyable living environment for the residents, Keperra Sanctuary provides a variety of facilities and services in the community centre 
area. The public facilities are important for providing a sustainable community for the residents. With better health conditions and a longer life span than previous generations, older people still engage heavily in social activities. The public facilities and units provided in the village should help facilitate their social needs. Additionally, for those with comparatively reduced physical capabilities, the facilities provided should be easy-to-operate and help improve their health conditions. Most of the facilities provided in the community centre are widely used by residents. For example, the solar heated swimming pool is very popular with the residents and their families, and physical training programmes have been frequently held in the pool. Residents have access to a craft workshop once they have attend a safety-training program, use the community centre for private functions and family gatherings, and borrow books, jigsaws, puzzles or DVDs from the library (see Table 1 for a summary of all the villages' facilities).

To meet the unique daily requirements of residents, various services are available for those in need. These services include, for example, buggy rides as internal transportation within the village, a shuttle bus to travel to the local shopping centre or Brisbane city, chemist delivery, church services in the community centre, garden maintenance, and even a health service. The village has a 24 -hour staff facility with a room and equipment in case of emergency. Residents need only press the emergency button located on their pendant and kitchen telephone for a bleeped signal to be sent to staff. There is a village coordinator responsible for the residents' health and emotional issues. Should any residents feel isolated living in the village, they can contact the village coordinator, who will often suggest, for example, having coffee at the community centre so that they can talk with others, or go for a short walk instead of just sitting in the unit. It is the intention of the village that its residents enjoy their life in the village and are involved in its social activities.

\section{Internal communication and social activities}

Communication and information sharing among residents is very important for their daily life. Various means of communication are available, such as a notice board, resident newsletters, webpage (http://myksrv.com/) and mini screen. The notice board is located inside the community centre and allows residents and managers to announce any activities and events, such as monthly dinners and residents' committee meetings. The Village Residents Web Page is produced by the residents for the residents. Through this, they can find out all that is going on in the Village. Multi screens broadcast information to every unit. Residents organise their own newsletters and distribute them monthly. Managers also provide a brief report to residents every month. This contains news from the facility manager and other staff such as sales officers, maintenance officers and the village coordinator and helps to maintain the relationship between residents and village managers.

A self-organized residents committee also helps in maintaining relations between resident-resident and resident-managers by bridging resident and manager communications. Having happier residents makes the sanctuary a better place to live. Additionally, a better relationship between the village managers and the committee leads to a better relationship between managers and other residents, which helps the whole village to be managed effectively and efficiently.

The residents organise their own weekly fruit and vegetable market in the village, with produce sometimes harvested from residents' garden. In addition to helping other residents, this activity also generates a micro economy in the village.

Table 1. Facilities and services provided in the village

\begin{tabular}{ll}
\hline Items provided \\
\hline Facilities & Alfresco Dining Area, Bar, Barbecue, Billiards Table(s), Boat Storage, Bowling Green, Bridge Club, \\
& Business Centre, Caravan Storage, Community Centre/Clubhouse, Conference Room, Craft \& Hobby \\
& Room, Croquet Lawn, Dance Floor, Function Room, Games Room, Golf Course Nearby, Hairdressing \\
& Salon/Barber, Hobby Shed, Indoor Bowls, Library, Lounge, Men's Shed, Pet Friendly, Social Activities \& \\
& Clubs, Swimming Pool, TV/DVD, Table Tennis Table, Village Bus, Workshop
\end{tabular}

Services $\quad$ Aged Care On-site, Deliveries from Chemist, Emergency Call System, Ice Cream Delivery, Manager On-site, Milk Delivery, Newspaper Delivery, On-site Classes, Visiting Medical Practitioners, Visiting Hairdresser/Barber, Visiting Podiatrist, Visiting Acupuncturist 


\section{Social performance}

In a follow-up questionnaire survey, which was conducted to obtain the residents' understanding, attitude and awareness of sustainability, it is encouraging to find that $42 \%$ of the 65 respondents "usually" attend social activities such as community events with other residents, with $46 \%$ "always" attending these events. Only $3 \%$ of the residents "never" and 9\% "rarely" attend social activities mainly due to their physical conditions. In addition, it is also impressive to find that $41 \%$ respondents "usually" and 36\% "always" take part in activities such as gardening, sports, dancing, and making crafts to keep them physically active.

Almost all the respondents (98\%) believe that social activities, friendships and social networks are important for their quality of life. The village managers also realize the importance of this, and create opportunities for residents to develop friendship networks and participate in a wide range of activities in the village and the wider community. Although, the number of respondents to the survey only represents around $25 \%$ of the total residents of the 254 units, the findings from the survey have been largely confirmed with the in-depth interviews with village managers and individual residents.

\section{Cost and affordability}

The price of the houses in the village ranges over $\$ 275,000$ for a one-bedroom house, $\$ 290,000$ for a two-bedroom house, $\$ 399,000$ for a three-bedroom house, $\$ 405,000$ for a two-bedroom apartment and $\$ 505,000$ for a three-bedroom apartment. Potential residents can secure a property with a $\$ 1,000$ deposit. This is fully refundable if they decide not to go ahead with the purchase.

In addition to the purchase price, there is an on-going service fee or levy to pay for the day-today operating costs and upkeep of the village. This levy is used to cover services such as monitoring the emergency call and response system, maintaining and cleaning the recreational facilities and common areas that are available to all residents, including the gardens and lawns, and managing the village. It includes salaries, covering the cost of running the recreational facilities (e.g. gas and electricity) and building insurances. This is currently just over $\$ 500$ per month, of which the village make no profit. Some services may require an extra fee, such as for visiting health professionals, exercise classes run by qualified trainers or physiologists, visiting hairdressers and/or beauty therapists or extra help around the home.
When the residents sell their property, they need to pay a Deferred Management Fee (DMF), also known as an 'exit fee', which helps cover initial investment in the land and the construction of the village infrastructure and community facilities specifically designed to provide residents with an environment that promotes healthy living, wellness, spiritual connection and a good quality of life. The DMF at Keperra Sanctuary is capped at $30 \%$ of the purchase price for 9 years of occupancy, and the village retains $100 \%$ of any capital gain arising from the sale.

Although the retirement village is market oriented, it is thought to be within the current affordability of residents due to the very low ongoing vacancy rate, which is around $6-8 \%$ at any one time. The village sells around 22 units per year.

\section{DISCUSSION}

The Keperra Sanctuary is a 20 year old private, ongoing retirement village, located in a suburban area of Brisbane on the east coast of Australia. Due to the unique characteristics of this location (e.g. weather conditions, target customer etc.), some of the findings are applicable to this retirement village only. However, the majority of the sustainable solutions (e.g. sustainable planning and design, social activities and service etc.) can provide a useful reference for other retirement villages. More importantly, as the concept of sustainable retirement villages is comparatively new, the case study will help to provide some insights into what is involved.

Although it is an existing retirement village operated for more than 20 years, the case study indicates that the Keperra Sanctuary still demonstrates a high level of environmentally sustainability, which is mainly due to the adoption of environmentally sustainable design practices during its early design and planning stages. Sustainable design reduces the use of non-renewable resources, minimises impact on the environment and connects people with the natural environment. Through the careful selection of the retirement village's location on the north side of a hill with natural bushland, the adoption of sustainable architecture (e.g. north facing windows and doors), and use of energy efficiency materials, the village is environmentally friendly without modern energy saving technologies and appliances.

The facilities provided play a vital role in the sustainable lifestyle of the residents. As social activities and social relationships are critical for 
maintaining quality of life in older age (e.g. Cattan et al. 2005; Borglin et al. 2006), it is of great importance to provide facilities that adequately support a good level of social engagement. Retirement villages were once provided by not-for-profit organizations, which sought to meet a basic need of services and security (Stimson 2002). In the current retirement village market however, there are a growing number of villages that are operated by private companies, which are normally property developers with retirement divisions. In order to attract more residents to private retirement villages, an increasing number of facilities are provided to facilitate social engagement and increase belongingness of the community. The follow-up questionnaire survey showed that residents in retirement villages use these facilities frequently in their daily life, and recognize their important contribution to their health and quality of life. Therefore, the number and kind of facilities provided in retirement villages, to some extent, reflects the quality of the living environment within the village.

Social sustainability is the major highlight and sale point of the case study village. Older people need and want to be active in their everyday lives and participate in social activities (Valdemarsson et al. 2005). A retirement village should be pleasant to live in, has community spirit, good facilities and leisure activities. In Keperra Sanctuary, most of the respondents (more than 90\%) agree with the importance of attending social group activities and having sufficient engagement with other village residents (Xia et al. 2014). Additionally, the village maintains the culture of a traditional neighbourhood where people care about their neighbours and help each other. In fact, almost all the residents have very good relationships with their neighbours and village managers and often attend social group activities (with $42 \%$ "usually", and $46 \%$ "always"). As confirmed by the findings of previous research, older people need to remain socially active, as this is crucial in personal functioning in later life (Golden et al. 2009; Grundy, Read 2012) and retirement village developers need to create a living environment/community that facilitates residents' social activities and social relationships.

The cost of the living in Keperra Sanctuary is not cheap. However, most of the residents find it worthwhile as "they are buying the lifestyle" rather than a single property. This is particularly true for those who have been living in the village for a long time. These findings are different from those of another case study conducted in South Australia (Barker et al. 2012; Zuo et al. 2014), in which af- fordability was the major concern to residents although they still desired a sustainable living environment. The major reason is that the South Australian village is not-for-profit and its target residents are older people with middle to low incomes and living mainly on pensions. Keperra Sanctuary is a private retirement village, and affordability does not appear to be a concern to the residents as evidenced by its market oriented sale strategy and comparatively low vacancy rate - indicating a marked difference between the private and not-forprofit situations.

Retirement villages are no longer considered to be places where older people are herded together to pass the time of day (Hoonaard 2002). Instead, these communities are starting to challenge the negative perspectives of ageing, while positively influencing the health and wellbeing of the residents (e.g. Appleton 2002; Graham, Tuffin 2004). The sustainable retirement community provides an innovative perspective on the notion of ageingin-place and promotes a living environment supporting independent living and a good quality of life.

\section{CONCLUSIONS}

Studying the connections between aging and sustainability is potentially of great importance. A $\mathrm{SRV}$, which is environmentally friendly, financially affordable and socially supportive, helps to improve the life quality of its residents. For the Keperra Sanctuary, the environmentally friendly features that were incorporated into its development mainly include green design for the site and floor plan, adoption of thermal efficient building materials, window orientation, and waste management in its daily operation. More importantly, a variety of facilities (e.g. community centre, swimming pool and library) is provided to strengthen social engagement and interactions among its residents. Additionally, different daily services (e.g. the emergency call system and visiting medical practitioners) are provided to assist independent living and improve the health conditions of its residents. Finally, given the low vacancy rate in the village, it is believed that these sustainability features provide good value of money for the residents.

The increasing proportion of aging population makes the provision of sustainable housing for older people of great importance to society today. For a variety of reasons (health status, lack of security, difficulty managing a large property, social isola- 
tion, poor public transport, loneliness, desire for alternative lifestyle, etc.), many older people face the prospect of major changes in life-style, such as the loss of independence and privacy. Retirement villages need to be responsive to this in the form of dynamic environments for independent living and good quality of life. Currently, however, most do not do this and fail to fully address even such basic needs of older people as size, energy efficiency and requirements for ongoing maintenance, provision of social activities and belongingness. There is an urgent need for retirement villages to adequately house and care for the growing aging population and to provide a living environment that fully addresses the ergonomic requirements of older people, their reduced financial situation and social needs for an active aging life style.

The research findings point to some practical implications for project developers and operators. Firstly, it is necessary for environmental sustainability to be taken into account during all project stages. Considerations made in the planning, design, tender, construction and operation stages provide developers and managers provide the foundation for determining the sustainability features that need to be incorporated, and the workforce necessary for managing and monitoring the operation and maintenance involved. Secondly, a SRV that can significantly improve the life quality of older people may be used as a selling point for developers.

The major limitation of this study results from the lack of precise data to quantify the benefits associated with the sustainability features adopted. Additionally, there is a lack of thorough understanding of the perceptions of residents towards sustainability values. Future research would benefit from a better understanding of the consumers' understanding of sustainability concepts and their willingness to pay for sustainable features and quantification of the actual associated benefits and costs involved. In addition, case studies in other locations would enable local and international comparisons to be made.

\section{ACKNOWLEDGEMENTS}

The work described in the paper was supported by the Research Trust of the Royal Institute of Chartered Surveyors (RICS). Especial thanks are given to mangers and residents in Keperra Sanctuary, Lend Lease for offering kind support and useful information for the completion of this study.

\section{REFERENCES}

Appleton, N. 2002. Planning for the majority: the needs and aspirations of older people in general housing. York: Joseph Rowntree Foundation.

Australia Bureau of Statistics. 2010. Population by age and sex, Australian States and Territories, Jun 2010. Available at: http://www.abs.gov.au/ausstats/abs@. nsf/mf/3201.0 [accessed June 2011]

Barker, J.; Zuo, J.; Xia, B.; Zillante, G. 2012. Sustainable retirement living: what matters, in Proceedings of the 37th Annual Conference of Australasian University Building Educators Association (AUBEA), 4-6 July 2012, NSW.

Bernard, M.; Bartlam, B.; Sim, J.; Biggs, S. 2007. Housing and care for older people: life in an English purpose-built retirement village, Aging and Society 27(4): 555-578. http://dx.doi.org/10.1017/ S0144686X07005983

Borglin, G.; Jakobsson, U.; Edberg, A. K.; Hallberg, I. R. 2006. Older people in Sweden with various degrees of present quality of life: their health, social support, everyday activities and sense of coherence, Health \& Social Care in the Community 14: 136-146. http:// dx.doi.org/10.1111/j.1365-2524.2006.00603.x

Buys, L. 2000. Care and support assistance provided in retirement villages: expectations vs. reality, Australasian Journal on Ageing 19(3): 149-151. http:// dx.doi.org/10.1111/j.1741-6612.2000.tb00168.x

Buys, L. 2001. Life in a retirement village: implications for contact with community and village friends, Gerontology 47(1): 55-59. http://dx.doi. org/10.1159/000052771

Buys, L.; Miller, E. 2007. The physical, leisure and social activities of very old Australian men living in a retirement village and the community, Geriaction 25(2): 15-19.

Cattan, M.; White, M.; Bond, J.; Learmouth, A. 2005. Preventing social isolation and loneliness among older people: a systematic review of health promotion interventions, Ageing \& Society 25: 41-67. http:// dx.doi.org/10.1017/S0144686X04002594

Cornwell, E. Y.; Waite, L. J. 2009. Social disconnectedness, perceived isolation, and health among older adults, Journal of Health and Social Behavior 50(1): 31-48.

Cotter, N.; Monahan, E.; McAvoy, H.; Goodman, P. 2012. Coping with the cold-exploring relationships between cold housing, health and social wellbeing in a sample of older people in Ireland, Quality in Ageing and Older Adults 13(1): 38-47. http://dx.doi. org/10.1108/14717791211213607

Crisp, D. A.; Windsor, T. D.; Butterworth, P.; Anstey, K. J. 2013. What are older adults seeking? Factors encouraging or discouraging retirement village living, Australasian Journal on Ageing 32(3): 163-170. http://dx.doi.org/10.1111/j.1741-6612.2012.00623.x

Dul, J.; Bruder, R.; Buckle, P.; Carayon, P.; Falzon, P.; Marras, W. S.; Wilson, J. R.; van der Doelen, B. 2012. A strategy for human factors/ergonomics: developing the discipline and profession, Ergonomics 55(4): 377395. http://dx.doi.org/10.1080/00140139.2012.661087 
Gardner, I. L.; Browning, C.; Kendig, H. 2005. Accommodation options in later life: retirement village or community living?, Australasian Journal on Ageing 24(4): 188-195. http://dx.doi.org/10.1111/j.17416612.2005.00121.x

Gilleard, C.; Higgs, P. 2005. Contexts of ageing: class, cohort and community. Cambridge: Polity.

Golden, J.; Conroy, R. M.; Lawlor, B. A. 2009. Social support network structure in older people: underlying dimensions and association with psychological and physical health, Psychology, Health and Medicine 14(3): 280-290. http://dx.doi. org/10.1080/13548500902730135

Graham, V.; Tuffin, K. 2004. Retirement villages: companionship, privacy and security, Australasian Journal on Ageing 23(4): 184-188. http://dx.doi. org/10.1111/j.1741-6612.2004.00047.x

Grundy, E.; Read, S. 2012. Social contacts and receipt of help among older people in England: are there benefits of having more children?, The Journals of Gerontology Series B: Psychological Sciences and Social Sciences 67(6): 742-754. http://dx.doi.org/10.1093/ geronb/gbs082

Hoonaard, D. 2002. Life on the margins of a Florida retirement community: the experience of snowbirds, newcomers and widowed persons, Research on Ageing 24(1): 50-66. http://dx.doi. org/10.1177/0164027503024001004

Lawton, M. P. 1982. Competence, environmental press, and the adaptation of older people, in Lawton, M. P.; Windley, P. G.; Byerts, T. O. (Eds.). Aging and the environment, New York: Springer, 33-59.

Lawton, M. P.; Cohen, J. 1974. The generality of housing impact on the well-being of older people, Journal of Gerontology 29(2): 194-204. http://dx.doi.org/10.1093/ geronj/29.2.194

Lee, Y.; Yoon, H.; Lim, S.; An, S.; Hwang, J. 2012. Housing alternatives to promote holistic health of the fragile aged, Indoor and Built Environment 21(1): 191204. http://dx.doi.org/10.1177/1420326X11419349

NSW Fair Trading. 2011. Retirement village living: an overview of the NSW retirement village laws. Parramatta NSW 2150, March 2011.

Nummelin, J. 2005. Business potential in senior services, International Journal of Strategic Property Management 9(3): 191-200. http://dx.doi.org/10.1080/164 8715X.2005.9637536

Omoto, A. M.; Aldrich, C. D. 2006. Retirement community life: issues, challenges, and opportunities, Annual Review of Gerontology and Geriatrics 26(1): 283-303.

Pillemer, K.; Wells, N. M.; Wagenet, L. P.; Meador, R. H.; Parise, J. T. 2011. Environmental sustainability in an aging society: a research agenda, Journal of Aging and Health 23(3): 433-453. http://dx.doi. org/10.1177/0898264310381278

Pinto, M. R.; De Medici, S.; Zlotnicki, A.; Bianchi, A.; Van Sant, C.; Napou, C. 1997. Reduced visual acuity in elderly people: the role of ergonomics and gerontechnology, Age and Ageing 26(5): 339-344. http:// dx.doi.org/10.1093/ageing/26.5.339
Poterba, J. M.; Venti, S. F.; Wise, D. A. 2011. The composition and draw-down of wealth in retirement, No. w17536. National Bureau of Economic Research. http://dx.doi.org/10.3386/w17536

RVA 2011. A sustainable population strategy for Australia. Submission to the Department of Sustainability, Environment, Water, Population and Communities. Retirement Village Association (RVA), March 2011.

Sibley, J.; Hes, D.; Martin, F. 2003. A triple helix approach: an inter-disciplinary approach to research into sustainability in outer-suburban housing estates, in Proceedings of Methodologies in Housing Research Conference, September 2003, Stockholm.

Sridhar, K. 2011. A multi-dimensional criticism of the Triple Bottom Line reporting approach, International Journal of Business Governance and Ethics 6(1): 49-67. http://dx.doi.org/10.1504/IJBGE.2011.037606

Stein, J.; Schettler, T.; Rohrer, B.; Valenti, M. 2008. Environmental threats to healthy aging. Boston: Greater Boston Physicians for Social Responsibility and Science and Environmental Health Network. Available at: http://www.agehealthy.org/

Stimson, R. 2002. The retirement village industry in Australia: evolution, prospects, challenges. Brisbane: University of Queensland Press.

United Nations 2002. World population ageing 19502050. New York: United Nations.

Valdemarsson, M.; Jernryd, E.; Iwarsson 2005. Preferences and frequencies of visits to public facilities in old age-a pilot study in a Swedish town center, Archives of Gerontology and Geriatrics 40(1): 15-28. http://dx.doi.org/10.1016/j.archger.2004.05.010

Wargocki, P.; Wyon, D. P. 2012. Providing better thermal and air quality conditions in school classrooms would be cost-effective, Building and Environment 59: 581589. http://dx.doi.org/10.1016/j.buildenv.2012.10.007

Wahl, H.W.; Gitlin, L. N. 2007. Environmental gerontology, in Birren, J. E. (Ed.). Encyclopedia of gerontology. Age, aging, and the aged, $2^{\text {nd }}$ ed. Oxford: Elsevier, 494-501.

Xia, B.; Skitmore, M.; Zuo, J.; Pullen, S.; Chen, Q. 2013. Green Star points obtained by Australian building projects, Journal of Architectural Engineering 19(4): 302-308. http://dx.doi.org/10.1061/(ASCE)AE.19435568.0000121

Xia, B.; Zuo, J.; Skitmore, M.; Buys, L.; Hu, X. 2014. Sustainability literacy of older people in retirement villages, Journal of Aging Research 2014, Article ID 919054, 7 pages. http://dx.doi. org/10.1155/2014/919054

Zuo, J.; Xia, B.; Barker, J.; Skitmore, M. 2014. Green buildings for greying people: a case study of a retirement village in Australia, Facilities 32(7-8): 365381. http://dx.doi.org/10.1108/F-08-2011-0060

Zuo, J.; Zhao, Z. Y. 2014. Green building research-current status and future agenda: a review, Renewable and Sustainable Energy Reviews 30: 271-281. http:// dx.doi.org/10.1016/j.rser.2013.10.021 